\title{
Effect of Hypoxia on Expression of Selected Proteins Involved in Regulation of Apoptotic Activity in Striatum of Newborn Piglets
}

\author{
A. Mammen · J. Kubin • W. J. Greeley • \\ G. J. Schears $\cdot$ P. Pastuszko $\cdot$ D. F Wilson • \\ A. Pastuszko
}

Accepted: 29 December 2010/Published online: 13 January 2011

(C) The Author(s) 2011. This article is published with open access at Springerlink.com

\begin{abstract}
The levels of selected neuroregulatory proteins that inhibit or promote apoptotic cell death were measured in the striatum of piglets subjected to precisely controlled $1 \mathrm{~h}$ hypoxic insult followed by 0,2 and $4 \mathrm{~h}$ recovery and compared to sham operated animals. The anti-apoptotic proteins: there were increases in Survivin at $0(157 \%$, $P=0.031)$ and $4 \mathrm{~h}(171 \%, P=0.033)$, in Bcl-XL at 0 $(138 \%, P=0.028)$ and $4 \mathrm{~h}(143 \%, P=0.007)$, in VEGF at $4 \mathrm{~h}(185 \%, P=0.019)$ and $\mathrm{Hsp} 27$ at $2 \mathrm{~h}(144 \%$, $P=0.05)$ and $4 \mathrm{~h}(143 \%, P=0.05)$. The pro-apoptotic proteins: caspases-1 and 7 increased at $4 \mathrm{~h}(135 \%, P=$ $0.05)$ and $(129 \%, P=0.038)$, respectively. Bim increased after $4 \mathrm{~h}(115 \%, P=0.028)$, Apoptosis Inducing Factor after $2 \mathrm{~h}(127 \%, P=0.048)$ and Calpain after $4 \mathrm{~h}(143 \%$ of control, $P=0.04)$. Hypoxia causes increase in levels of both anti- and pro-apoptotic proteins. Their relative activity determines the outcome in terms of cell damage and neuronal deficit.
\end{abstract}

\footnotetext{
A. Mammen · W. J. Greeley

Department of Anesthesiology and Critical Care Medicine, Children's Hospital of Philadelphia, University of Pennsylvania, Philadelphia, USA

J. Kubin · D. F Wilson · A. Pastuszko ( $\square)$

Department Biochemistry and Biophysics, School of Medicine, University of Pennsylvania, 264 Anatomy Chemistry Bldg., Philadelphia, PA 19104, USA

e-mail: pastuszk@mail.med.upenn.edu

\section{G. J. Schears}

Department of Anesthesiology, Mayo Clinic, Minneapolis, MN, USA

P. Pastuszko

Department of Surgery, University of California-San Diego, San Diego, CA, USA
}

Keywords Newborn brain - Hypoxic injury · Apoptotic neuronal injury $\cdot$ Striatal injury

\section{Introduction}

Neonatal brain injury resulting from hypoxia-ischemia is a most common form of brain damage and can lead to various neurological disorders [1-3]. Hypoxia is etiologically linked to cerebral palsy, hearing and vision loss, mental retardation, learning disabilities, attention deficit hyperactivity disorder, schizophrenia and neuronal migration disorders.

The mechanisms underlying hypoxic-ischemic brain damage are only partially understood but it is well established that following hypoxia-ischemia of neonatal brain, neuronal death can occurs by both apoptosis and necrosis [4-6]. However, the relative involvement of necrosis and apoptosis to the injury that develops after cerebral hypoxia-ischemia is still not clear [7]. The occurrence of these processes has been reported to be dependent on the severity and duration of insult and also on the region and degree of maturation of the brain [8-10]. Numerous studies have reported that, following hypoxia-ischemia in the neonatal brain, there is greater apoptotic than necrotic cell death and that, in neonates, hypoxia can activate several pro-apoptotic pathways [9-11]. Some of the pro-apoptotic regulatory proteins involved in this process include caspases, members of the Bcl-2 protein family such as Bax, $\mathrm{Bad}$, Bid or Bim, apoptosis inducing factor (AIF), and calpain-calcium binding protease.

Over-expression of other proteins that can occur following hypoxia-ischemia, such as anti-apoptotic proteins of the Bcl-2 protein family- Bcl-2 or Bcl-XL, Survivin, VEGF, hypoxia inducing factor -27 (Hsp-27) are known to suppress apoptotic cell death. 
Our previous studies revealed significant regional differences in expression of Bcl-2 and Bax (the Bcl-2/Bax ratio is considered an indicator of apoptotic pathway activation) in the brain of newborn piglet following $1 \mathrm{~h}$ hypoxia. The Bcl-2/Bax ratio was lower in the striatum than in other brain regions, suggesting that the striatum may be particularly susceptible to apoptotic injury.

The purpose of the present investigation was to assess the responses of other pro- and anti-apoptotic proteins in the striatum of newborn piglets in the same hypoxia model.

\section{Experimental Procedure}

\section{Animal Preparation}

Newborn piglets, age 3-5 days, were used for this study. Anesthesia was induced with $4 \%$ isoflurane (Novaplus, Hospira Inc., Lake Forest, IL). Pulse oximetry, ECG and temperature measurements begun immediately after induction of anesthesia. A 1.0\% lidocaine- $\mathrm{HCl}$ (Abbott Laboratories, North Chicago, IL) was used as a local anesthetic for tracheotomy and insertion of femoral arterial and venous lines. A bolus of fentanyl citrate $(30 \mu \mathrm{g} / \mathrm{kg})$ was administered intravenously (IV). Monitoring of systemic blood pressure and heart rate began immediately following insertion of the arterial line and blood gas measurements $\left(\mathrm{pO}_{2}, \mathrm{pCO}_{2}, \mathrm{pH}\right.$, glucose, and ions) were made at regular intervals throughout the procedure. Isoflurane was reduced to $1 \%$ after tracheotomy and pancuronium (Apothecon, Bristol-Meyers Squibb, Princeton, NJ) was injected $(0.3 \mathrm{mg} / \mathrm{kg}$, IV) to help maintain a balanced anesthesia and to induce respiratory paralysis. The piglets were placed on mechanical ventilation (Sechrist Infant Ventilator, model IV-100 B), isoflurane was withdrawn entirely and piglets were ventilated with a mixture of oxygen and nitrous oxide (at control condition with $21-22 \%$ oxygen and $79-78 \%$ nitrous oxide). Anesthesia was maintained during the experiments using nitrous oxide, fentanyl $(10 \mu \mathrm{g} / \mathrm{kg} / \mathrm{h}, \mathrm{IV})$ and pancuronium $(0.1 \mathrm{mg} / \mathrm{kg}$, IV). This model provides a balanced anesthesia using an inhalation agent (nitrous oxide) for amnesia and analgesia, a potent fast acting narcotic agent (fentanyl) for primary analgesia, and a neuromuscular blocking agent (pancuronium) to provide surgical and experimental stillness and control of ventilation. The piglets were monitored closely and any increase in heart rate or blood pressure of more than $10 \%$ was treated with supplemental fentanyl at a dose sufficient to return the values of control levels.

Blood pressure, body temperature, heart rate and endtidal $\mathrm{CO}_{2}$ were continuously monitored. Arterial blood samples were taken every $15 \mathrm{~min}$ and blood $\mathrm{pH}$, arterial $\mathrm{CO}_{2}$ pressure $\left(\mathrm{PaCO}_{2}\right)$ and arterial oxygen pressure $\left(\mathrm{PaO}_{2}\right)$ were measured using a Rapid Lab 850 Analyzer (Bayer). Hydration was maintained by iv injection of physiological saline as needed. At the conclusion of the experiments, the anesthetized animals were euthanized by intravenous administration of saturated $\mathrm{KCl}$ solution. After euthanasia the brain was quickly removed and placed in $0-4^{\circ} \mathrm{C}$ saline solution, a medial cut used to separate it into the left and right halves and the all of the striatum, putamen and caudate nucleus, dissected out. The striatal tissue was rapidly frozen by placing it on aluminum foil lying in a bed of powdered dry ice. The frozen tissue was stored at $-80^{\circ} \mathrm{C}$ until use.

All animal use procedures were in strict accordance with the NIH Guide for the Care and Use of Laboratory Animals and were approved by the local Animal Care Committee.

\section{Experimental Model}

Hypoxia was induced by changing the $\mathrm{FiO}_{2}$ from 21 to $6 \%$, lowering the mean cortical oxygen pressure to $10 \mathrm{~mm} \mathrm{Hg}$ over $20 \mathrm{~min}$ and then holding a level of $8 \mathrm{~mm} \mathrm{Hg}$ for $40 \mathrm{~min}$ followed by reoxygenation with $21 \% \mathrm{FiO}_{2}$ for 0,2 or $4 \mathrm{~h}$.

\section{Protein Array (Full Moon Bioscience)}

\section{Protein Labeling}

Labeling reagent was prepared by adding $100 \mu$ of DMF to $1 \mathrm{mg}$ of biotin reagent was added to a final concentration of $10 \mu \mathrm{g} / \mu \mathrm{l}$. Labeling buffer was added to a homogenate of the striatal tissue containing $145 \mu \mathrm{g}$ protein to bring the volume to $50 \mu \mathrm{l}$ and then $2 \mu \mathrm{l}$ of the biotin/DMF was added to the protein sample with labeling buffer. The solution was mixed and incubated at room temperature (RT) for $2 \mathrm{~h}$ with mixing. Twenty five micro litre of stop reagent was added and the mixture incubated for $30 \mathrm{~min}$ at RT with mixing.

\section{Coupling}

The Antibody Microarrays were submerged in blocking buffer and shaken for $40 \mathrm{~min}$ at RT. The arrays were rinsed with Milli-Q grade deionized (DI) water and incubated in the coupling chamber with $145 \mu \mathrm{g}$ of labeled protein sample in $6 \mathrm{ml}$ coupling solution on an orbital shaker for $2 \mathrm{~h}$ at RT. The slides were removed from the coupling chamber, washed three times with fresh wash buffer, and rinsed extensively with DI water.

\section{Detection}

Thirty micro litre of Cy3-Streptavidin $(1 \mathrm{mg} / \mathrm{ml})$ was added to a $60-\mathrm{ml}$ bottle containing detection buffer. The 
arrays were submerged in $30 \mathrm{ml}$ of Cy3-Streptavidin solution and incubated on an orbital shaker for $45 \mathrm{~min}$ at RT in the dark. The slides were washed three times with fresh wash buffer and rinsed extensively with DI water. They were then dried with compressed nitrogen and scanned on an Axon GenePix Array Scanner.

\section{Data Analysis}

Scanned images of microarrays were analyzed using Scion Image software $(\mathrm{NIH})$. The data are presented as the mean \pm SEM for the density of bands for six independent experiments in each group. This is an exploratory study. We did not adjust for type 1 errors and statistical significance of differences were assessed using a two-tailed $t$ test with $P<0.05$ considered significant. Our hypothesis, that hypoxia would result in significant increase in pro and anti apoptotic signaling in the striatum, predicts a direction for the changes in protein levels and a one tailed $t$ test would be appropriate. However, multiple pro and anti apoptotic proteins were measured in the same samples and a correction for multiple comparisons would be appropriate. Using both the one tailed $t$ test and Bonferroni's correction for multiple comparisons, which is generally believed to underestimate the significance, significance at the $95 \%$ for any one of the proteins being different from control would be equivalent to $P<0.03$ calculated by the two tailed $t$ test.

\section{Results}

Effect of Hypoxia on Early Response of Selected Anti-Apoptotic Proteins in the Striatum of Newborn Piglets

There were no significant differences as compared to sham operated animals in expression of Bcl-2, Bcl-2a, Bcl-6 and Bcl-XL. There were, however, significant increases in the levels of several other proteins believed to have significant roles in protection of the brain from hypoxic injury (Fig. 1a-d). As can be seen in Fig. 1a, at $0 \mathrm{~h}$ level of Survivin increased from $2,749 \pm 475$ to $4,326 \pm 414$ arbitrary units $(157 \%$ of control, $P=0.031)$ and by $4 \mathrm{~h}$ to $4,705 \pm 631$ arbitrary units (171\% of control, $P=0.033$ ). Similarly, Bcl-XL increased significantly as compared to control at $0 \mathrm{~h}$ from $12,807 \pm 1,162$ to $17,666 \pm 1,485$ arbitrary units (138\% of control, $P=0.028)$ and $4 \mathrm{~h}$ of recovery to $18,323 \pm 1,115$ arbitrary units $(143 \%$ of control, $P=0.007$; Fig. 1b). VEGF was also increased, from $1,382 \pm 276$ to $2,560 \pm 317$ arbitrary units $(185 \%$ of control, $P=0.019$ ) after $4 \mathrm{~h}$ of recovery (Fig. 1c) and Hsp27 increased from $5,137 \pm 859$ arbitrary units to $7,379 \pm 528$ arbitrary units after $2 \mathrm{~h}$ of recovery $(144 \%$ of control, $P=0.05)$ and to $7,343 \pm 524$ arbitrary units after 4 h $(143 \%$ of control, $P=0.05$; Fig. 1 d).

Effect of Hypoxia on the Early Response of Selected Pro-Apoptotic Proteins in the Striatum of Newborn Piglets

There were no significant differences between sham operated animals and post-hypoxic groups in levels of Caspase$2,-3,-5,-6,-8$ and -9 . Increase in expression of Caspase-7 from $1,947 \pm 192$ arbitrary units to $2,508 \pm 136$ arbitrary units was observed at $4 \mathrm{~h}$ of post-hypoxic recovery (129\% of control, $P=0.038$; Fig. 2a). Similarly, Caspase- 1 was increased significantly from $2,878 \pm 303$ to $3,884 \pm 377$ arbitrary units after $4 \mathrm{~h}$ of recovery (135\% of control, $P=0.05$; Fig. 2b). Bim expression was increased after $4 \mathrm{~h}$ from $539 \pm 21$ to $621 \pm 24$ arbitrary units $(115 \%$ of control, $P=0.028$; Fig. 3a). Apoptosis Inducing Factor was increased after $2 \mathrm{~h}$ of recovery from $5,636 \pm 485$ to $7,130 \pm 452$ arbitrary units (127\% of control, $P=0.048$ and at $4 \mathrm{~h}$ to $7,643 \pm 512$ arbitrary units $(136 \%$ of control, $P=0.017$; Fig. 3b). Calpain was increased from $5,004 \pm 691$ to $7,181 \pm 609$ arbitrary units $(143 \%$ of control, $P=0.04$ ) after $4 \mathrm{~h}$ of recovery (Fig. $3 \mathrm{c}$ ).

\section{Discussion}

Hypoxic/ischemic insult to the brain activates a number of pathways, some of which, if unopposed, lead to apoptotic or necrotic neuronal damage while others have a protective role, in part by countering the former. The data presented in this paper show that, in the striatum of newborn piglets, hypoxic insult results in rapid changes in expression of many proteins believed to regulate the processes that both promote and prevent apoptotic cell death. Striatum was chosen for this study because we have shown earlier that this region is particularly sensitive to hypoxia [12]. This was manifested by significant decrease in Bcl-2/Bax ratio, an indicator of an increased susceptibility of cells to apoptosis.

Each protein, reported in this study to undergo significant changes in response to hypoxic insult to the brain, is considered likely to have a significant role in determining the outcome of the apoptotic process. Survivin, VEGF, Bcl-XL and Hsp27 have been shown to be elevated following the hypoxic episode and all these proteins have been reported to help protect cells by inhibiting the processes leading to apoptotic death.

Survivin is a member of the inhibitor of apoptosis protein family (IAP family) and is reported to diminish apoptosis by interfering with the activity of caspase-3, caspase-7, and caspase-9 [13-16]. Additionally, Survivin 

(a), Bcl-XL (b), VEGF (c) and Hsp27 (d) in the striatum of newborn piglets at 0,2 and $4 \mathrm{~h}$ of post-hypoxic recovery. Analysis was of homogenates of striatal tissue. The data are presented as the mean \pm SEM for the density of bands for six independent experiments. The statistical significance of assessed using a two-tailed $t$ test with $P<0.05$ considered significant
Fig. 1 Expression of Survivin differences from control were
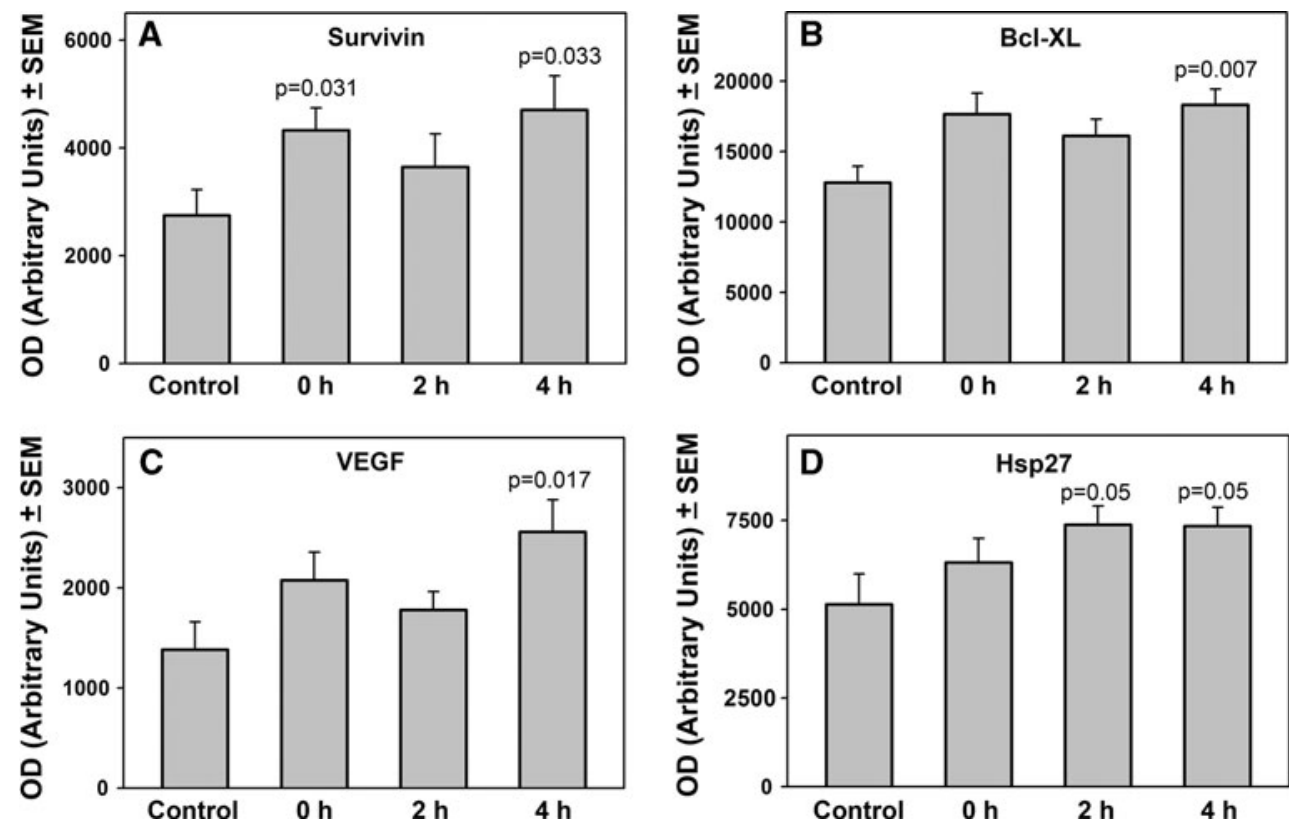

Fig. 2 Expression of Caspase-7 (a) and Caspase-1 (b) in the striatum of newborn piglets at 0 , 2 and $4 \mathrm{~h}$ of post-hypoxic recovery. The data are presented as the mean \pm SEM for the density of bands for six independent experiments
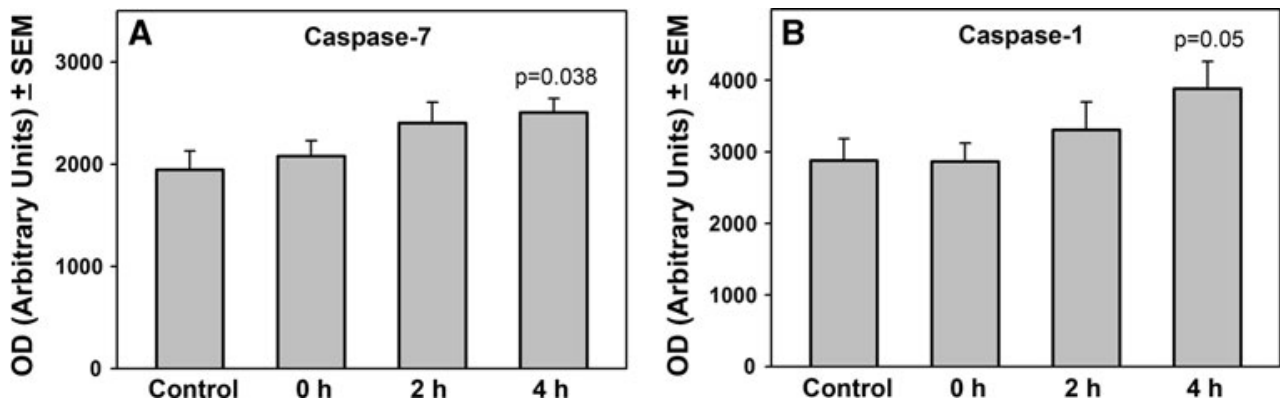

can increase cell survival through its effects on mitosis and cell cycle progression [17-21]. Conway et al. [22] reported that hypoxic/ischemic insult in a mouse stroke model resulted in increased expression of Survivin in the brain after 2 days of recovery. Our study shows that increase in expression of this protein occurs immediately after hypoxia, suggesting that Survivin can act quickly after a hypoxic insult as well as during prolonged recovery.

Survivin can be upregulated by angiogenic factors, including vascular endothelial cell growth factor (VEGF; $[23,24])$. Our data show that VEGF expression increased significantly only after $4 \mathrm{~h}$ of recovery whereas increase in expression of Survivin was observed already at the end of the hypoxic insult ( $0 \mathrm{~h}$ of recovery). Therefore, it can be suggested that, at least at $0 \mathrm{~h}$ of recovery, the increase of Survivin level occurred independently of VEGF. This is consistent with the report by Conway et al. [22] that hypoxia alone can induce Survivin expression in the brain, and this response is at least partially independent of VEGF.

The increase in VEGF observed after hypoxic insult in our study is consistent with reports of other investigators [25-29]. However, the role of this increase on apoptotic pathways in the newborn brain will require future investigation. VEGF has been reported to have two opposing roles in the brain. It can have pro-inflammatory properties and increases brain edema and tissue damage following ischemia [30]. On the other hand, it can also induce angiogenesis and increase vascular permeability [31,32], and these would be expected to be neuro-protective by inducing proliferation of astrocytes and preventing death of dopaminergic neurons [33]. As mentioned earlier, VEGF has been reported to have anti-apoptotic properties by up-regulation of Survivin, Akt and Bcl-2, key anti-apoptotic proteins [24, 34-36].

Another anti-apoptotic protein which was increased during post-hypoxic recovery is Bcl-XL. Bcl-XL has been proposed as a strong endogenous neuronal survival factor against neonatal hypoxic-ischemic injury [37]. Bcl-XL is an integral protein localized primarily in the mitochondrial membrane and had been shown to diminish cell death by suppressing release of apoptogenic proteins [38-40].

It was also observed increase in expression of Heatshock protein 27 (Hsp27) during post-hypoxic recovery. Hsp27 has several functions; one of them is regulation of 

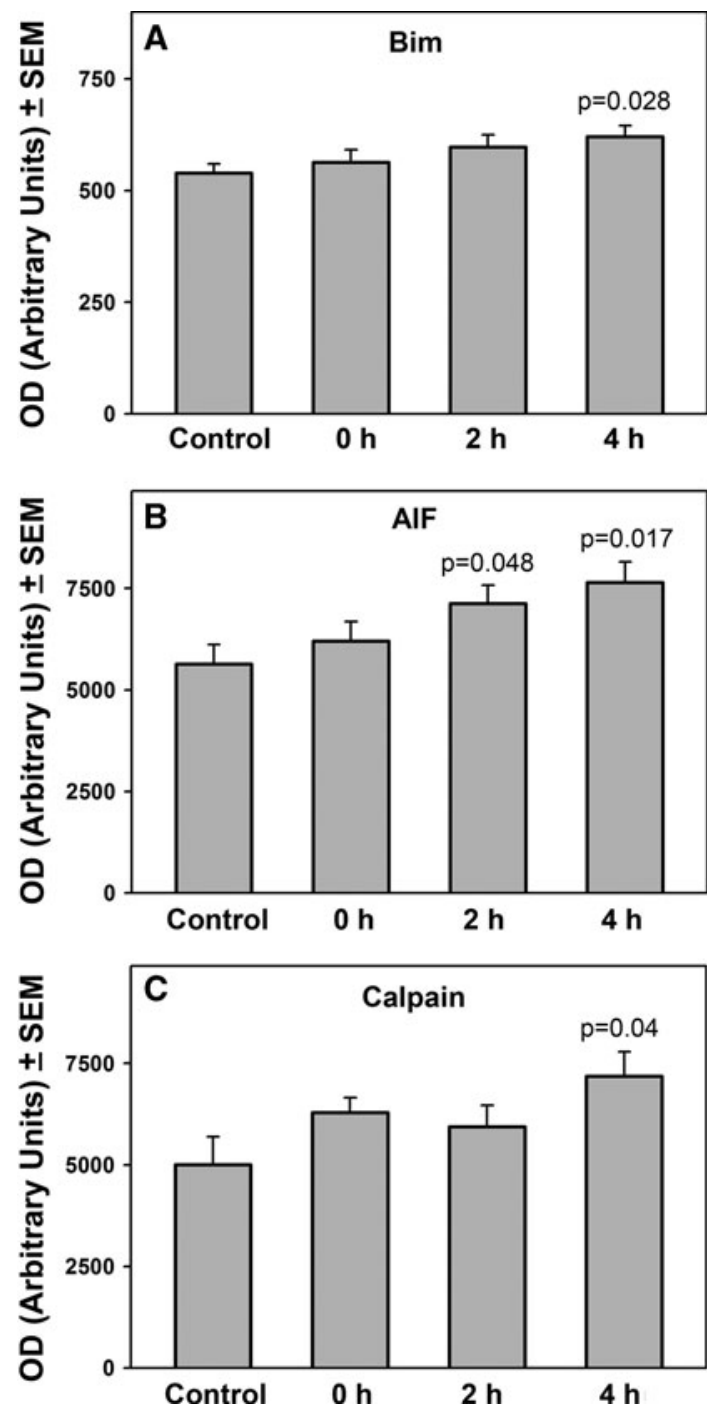

Fig. 3 Expression of Bim (a), AIF (b) and Calpain (c) in the striatum of newborn piglets at 0,2 and $4 \mathrm{~h}$ of post-hypoxic recovery. The data are presented as the mean \pm SEM for the density of bands for six independent experiments

apoptosis. It has been reported that Hsp27 interacts with outer mitochondrial membranes and, by interfering with the activation of cytochrome c-Apaf1-dATP complex, inhibits activation of procaspase-9 [41]. Hsp27 can also inhibit Daxx apoptotic protein and thus prevent association of Daxx with Fas and Ask1 [42].

It appears, not surprisingly, that cells stressed by hypoxic/ ischemic episode respond by increasing the amount of many proteins that help protect them from serious long term injury and/or death. These proteins form a coordinated stress response system designed to counter the deleterious effects of stressful episode on the cell, and affect almost every facet of the cell structure and metabolism. The question, therefore, arises: what is the response of some pro-apoptotic proteins in the striatum of the newborn to hypoxic insult?
In the present study, the levels of caspase- $2,-5,-6,-8$ and -9 did not change in response to the hypoxic episode when compared to sham operated animals. In contrast, caspase-1 and -7, as well as Bim, Apoptosis Inducing Factor (AIF), and calpain, were all significantly increased in the striatum after hypoxic-ischemic insult. Caspase-3 was not measured in the present study, but we have previously reported no significant changes in expression of this enzyme following hypoxic insult [12].

The caspase cascade plays a vital role in the induction, transduction, amplification and execution of apoptotic signals within the cell. Activation of caspases (cysteine proteases) is an essential component of the process of apoptosis [43]. Caspases have been reported to be activated after hypoxia-ischemia [6, 44] and inhibition of caspase activity has been reported to have neuroprotective effects in the immature brain [45, 46]. Upon their activation, through the intrinsic and/or extrinsic pathways, caspases can destroy essential cellular proteins, promoting controlled cell death. There are two tiers of caspase activation during apoptosis. Initiator caspases $(-2,-8,-9$ and -10) are activated through the apoptosis-signaling pathways and activate the effector caspases $(-3,-6$ and -7$)$ which, in an expanding cascade, carry out the apoptosis. In addition, caspase- 1 can activate inflammatory processes. The present study shows that hypoxic insult activates caspase- 1 and -7 . The increased expression of caspase- 1 is in agreement with other studies showing an increase of caspase-1 level in brain neurons in response to hypoxic insults both in vivo and in vitro [47, 48]. Caspase-1 catalyzes cleavage of inactive precursor of $\mathrm{IL}-1 \mathrm{~b}$ to generate mature cytokine. IL- $1 \mathrm{~b}$ acts to initiate inflammation, and this contributes to neuronal injury [49]. Caspase-7 had been generally characterized as an executioner of apoptosis [50]. However, Lakhani et al. [51] showed that this caspase plays also key role in the initial phase of apoptosis such as Bax translocation and cytochrome $\mathrm{c}$ release. Increase in activation of caspase-7 is in agreement with Yin et al. [52] who reported that in a rat pup model of hypoxia-ischemia caused activation of caspase 7 and also other caspases such as $-3,-8$ and -9. Lack of increase in expression of caspases-3, -8 and -9 in our study could be due to differences in severity of the hypoxic insult, animal age, species of experimental animals, and anatomical region examined.

When caspase activation is inhibited, neurons can still be injured through caspase-independent pathways [53, 54]. A major regulatory protein in caspase-independent cell death pathway is the apoptosis-inducing factor (AIF; [40, $55,56])$. AIF has been shown to increase apoptotic pathway induced by glutamate or oxidative stress [57, 58], trauma and ischemia $[59,60]$. The present study shown increase in expression of AIF during post-hypoxic recovery in striatum of newborn piglets. Data from literature indicated that after 
hypoxic-ischemic insult to the developing brain, AIF and caspases could act through parallel pathways that can lead to neuronal death $[61,62]$. Observed in our model, increase in expressions of caspase- 1 and -7 and AIF are consistent with the mechanism(s) of apoptotic injury proposed above by other investigators [61, 62]. Bim, a pro-apoptotic member of Bcl-2 family, is another protein up-regulated following hypoxia. Bim has been reported to play an important role in neuronal death following neonatal hypoxia-ischemia [63]. The authors reported that deficiency of the pro-apoptotic BH3-only molecules Bad or Bim is protective in the Rice-Vannucci model of neonatal hypoxia-ischemia. The increased level of Bim observed in our study is in agreement with the reports of other investigators showing that Bim increased following hypoxicischemic insults $[64,65]$. Another pro-apoptotic protein that increased following hypoxia was calpain, calcium binding protease. This is consistent with the report of Carloni et al. [66] showing significant increase in calpain $30 \mathrm{~min}$ after hypoxia-ischemia in a neonatal rat model. As response to hypoxia, there is increase in cytoplasmic free calcium derived from the combined influx of extracellular calcium and the release of calcium present in the endoplasmic reticulum (ER; [67]). This can activate calcium dependent proteins, such as calpain, related to cell death $[68,69]$.

In conclusion, this study was designed to gain understanding of the metabolic signaling changes that are initiated by hypoxic insult and can lead to cell loss through apoptosis. Through understanding the signaling processes associated with progression toward cellular injury and apoptotic cell death, it should be possible to design rational protective interventions. Such protective interventions would be designed to suppress pro-apoptotic and/or promote antiapoptotic signaling. Our results show that $1 \mathrm{~h}$ of hypoxic insult to newborn brain causes increases in the levels of several proteins which, if unopposed, can promote apoptotic or necrotic cell death. However, it also leads to increased levels of regulatory proteins that have protective roles, in part by countering the effects of the pro-apoptotic proteins. The final outcome, as measured in loss of brain cells and neuronal function, is determined by the relative activity of these pro- and anti- apoptotic regulatory processes. Treatments that preferentially favor one or the other process would be expected to markedly affect the final outcome.

Acknowledgments Supported in part by Grants NS-31465 and HL058669 from the US National Institutes of Health.

Open Access This article is distributed under the terms of the Creative Commons Attribution Noncommercial License which permits any noncommercial use, distribution, and reproduction in any medium, provided the original author(s) and source are credited.

\section{References}

1. Bracci R, Perrone S, Buonocore G (2006) The timing of neonatal brain damage. Biol Neonate 90:145-1552

2. Kadhim H, Sebire G, Kahn A et al (2005) Causal mechanisms underlying periventricular leukomalacia and cerebral palsy. Curr Pediatr Rev 1:1-63

3. Vexler ZS, Ferriero DM (2001) Molecular and biochemical mechanisms of perinatal brain injury. Semin Neonatol 6:99-108

4. Blomgren K, Zhu C, Wang X et al (2001) Synergistic activation of caspase- 3 by m-calpain after neonatal hypoxia-ischemia: a mechanism of 'pathological apoptosis'? J Biol Chem 276: 10191-10198

5. Hu BR, Liu CL, Ouyang Y et al (2000) Involvement of caspase-3 in cell death after hypoxia-ischemia declines during brain maturation. J Cereb Blood Flow Metab 20:1294-1300

6. Zhu C, Wang X, Xu F et al (2005) The influence of age on apoptotic and other mechanisms of cell death after cerebral hypoxia-ischemia. Cell Death Differ 12:162-176

7. Lee JM, Zipfel GJ, Choi DW (1999) The changing landscape of ischaemic brain injury mechanisms. Nature 399:A7-A14

8. Puka-Sundvall M, Gajkowska B, Cholewinski M et al (2000) Subcellular distribution of calcium and ultrastructural changes after cerebral hypoxia ischemia in immature rats. Brain Res Dev Brain Res 125:31-41

9. Northington FJ, Ferriero DM, Flock DL et al (2001) Delayed neurodegeneration in neonatal rat thalamus after hypoxia-ischemia is apoptosis. J Neurosci 21:1931-1938

10. Northington FJ, Ferriero DM, Martin LJ (2001) Neurodegeneration in the thalamus following neonatal hypoxia-ischemia is programmed cell death. Dev Neurosci 23:186-191

11. Felderhoff-Mueser U, Taylor DL, Greenwood K et al (2000) Fas/ CD95/APO-1 can function as a death receptor for neuronal cells in vitro and in vivo and is upregulated following cerebral hypoxic-ischemic injury to the developing rat brain. Brain Pathol 10:17-29

12. Pirzadeh A, Mammen A, Kubin J et al. (2010) Early regional response of apoptotic activity in newborn piglets brain following hypoxia and ischemia. Neurochem Res 36(1):83-92

13. Tamm I, Wang Y, Sausville E et al (1998) IAP-family protein survivin inhibits caspase activity and apoptosis induced by Fas (CD95), Bax, caspases, and anticancer drugs. Cancer Res 58: $5315-5320$

14. Shin S, Sung BJ, Cho YS et al (2001) An anti-apoptotic protein human survivin is a direct inhibitor of caspase-3 and -7. Biochemistry 40:1117-1123

15. Altieri DC (2003) Survivin in apoptosis control and cell cycle regulation in cancer. Prog Cell Cycle Res 5:447-452

16. Kobayashi K, Hatano M, Otaki M et al (1999) Expression of a murine homologue of the inhibitor of apoptosis protein is related to cell proliferation. Proc Natl Acad Sci USA 96:1457-1462

17. Ambrosini G, Adida C, Altieri D (1997) A novel anti-apoptosis gene, survivin, expressed in cancer and lymphoma. Nat Med 3:917-921

18. Skoufias DA, Mollinari C, Lacroix FB et al (2000) Human survivin is a kinetochore-associated passenger protein. J Cell Biol $51: 1575-1582$

19. Li F, Ackermann EJ, Bennett CF et al (1999) Pleiotropic celldivision defects and apoptosis induced by interference with survivin function. Nat Cell Biol 1:461-466

20. Uren AG, Wong L, Pakusch M et al (2000) Survivin and the inner centromere protein INCENP show similar cell-cycle localization and gene knockout phenotype. Curr Biol 10:1319-1328 
21. Li F, Ambrosini G, Chu EY et al (1998) Control of apoptosis and mitotic spindle checkpoint by survivin. Nature 396:580-584

22. Conway EM, Femke Zwerts F, Van Eygen V et al (2003) Survivin-dependent angiogenesis in ischemic brain. Molecular mechanisms of hypoxia-induced up-regulation. Am J Pathol 163: 935-946

23. Tran J, Rak J, Sheehan C et al (1999) Marked induction of the IAP family antiapoptotic proteins surviving and XIAP by VEGF in vascular endothelial cells. Biochem Biophys Res Comm 264: 781-788

24. O'Connor DS, Schechner JS, Adida C et al (2000) Control of apoptosis during angiogenesis by survivin expression in endothelial cells. Am J Pathol 156:393-398

25. Aly H, Hassanein S, Nada A et al (2009) Vascular endothelial growth factor in neonates with perinatal asphyxia. Brain Dev 31:600-604

26. Semenza GL (2000) HIF-1: mediator of physiological and pathophysiological responses to hypoxia. J Appl Physiol 88:1474-1480

27. Cheung CY (1997) Vascular endothelial growth factor: possible role in fetal development and placental function. J Soc Gynecol Investig 4:169-177

28. Marti HJ, Bernaudin M, Bellail A et al (2000) Hypoxia-induced vascular endothelial growth factor expression precedes neovascularization after cerebral ischemia. Am J Pathol 156:965-976

29. Lennmyr F, Ata KA, Funa K et al (1998) Expression of vascular endothelial growth factor (VEGF) and its receptors (Flt-1 and Flk-1) following permanent and transient occlusion of the middle cerebral artery in the rat. J Neuropathol Exp Neurol 57:874-882

30. Croll SD, Goodman JH, Scharfman HE (2004) Vascular endothelial growth factor (VEGF) in seizures: a double-edged sword. Adv Exp Med Biol 548:57-68

31. Gluzman-Poltorak Z, Cohen T, Herzog Y et al (2000) Nuropilin-2 is a receptor for the vascular endothelial growth factor (VEGF) forms VEGF-145 and VEGF-165. J Biol Chem 275:18040-18045

32. Saito Y, Uppal A, Byfield G et al (2008) Activated NAD(P)H oxidase from supplemental oxygen induces neovascularization independent of VEGF in retinopathy of prematurity model. Invest Ophthalm Vis Sci 49:1591-1598

33. Temburni MK, Jacob MH (2001) New functions for glia in the brain. Proc Natl Acad Sci USA 98:3631-3632

34. Dvorak HF (2002) Vascular permeability factor/vascular endothelial growth factor: a critical cytokine in tumor angiogenesis and a potential target for diagnosis and therapy. J Clin Oncol 20:4368-4380

35. Tran J, Rak J, Sheehan C et al (1999) Marked induction of the IAP family antiapoptotic proteins survivin and XIAP by VEGF in vascular endothelial cells. Biochem Biophys Res Comm 264:781-788

36. Zhu WH, MacIntyre A, Nicosia RF (2002) Regulation of angiogenesis by vascular endothelial growth factor and angiopoietin-1 in the rat aorta model: distinct temporal patterns of intracellular signaling correlate with induction of angiogenic sprouting. Am J Pathol 161:823-830

37. Parsadanian AS, Cheng Y, Keller-Peck CR et al (1998) Bcl-xL is an antiapoptotic regulator for postnatal CNS neurons. J Neurosci 18:1009-1019

38. Kluck RM, Bossy-Wetzel E, Green DR et al (1997) The release of cytochrome c from mitochondria: a primary site for Bcl-2 regulation of apoptosis. Science 275:1132-1136

39. Yang J, Liu X, Bhalla K et al (1997) Prevention of apoptosis by Bcl-2: release of cytochrome $\mathrm{c}$ from mitochondria blocked. Science 275:1129-1132

40. Susin SA, Lorenzo HK, Zamzami N et al (1999) Molecular characterization of mitochondrial apoptosis-inducing factor. Nature 397:441-446
41. Sarto C, Binz PA, Mocarelli P (2000) Heat shock proteins in human cancer. Electrophoresis 21:1218-1226

42. Charette SJ, Lavoie JN, Lambert H et al (2000) Inhibition of Daxx-mediated apoptosis by heat shock protein 27. Mol Cell Biol 20:7602-7612

43. Yuan J, Yankner BA (2000) Apoptosis in the nervous system. Nature 407:802-809

44. Hu BR, Liu CL, Ouyang Y et al (2000) Involvement of caspase-3 in cell death after hypoxia-ischemia declines during brain maturation. J Cereb Blood Flow Metab 20:1294-1300

45. Wang X, Zhu C, Hagberg H et al (2004) X-linked inhibitor of apoptosis (XIAP) protein protects against caspase activation and tissue loss after neonatal hypoxia-ischemia. Neurobiol Dis 16: 179-189

46. Cheng Y, Deshmukh M, D'Costa A et al (1998) Caspase inhibitor affords neuroprotection with delayed administration in a rat model of neonatal hypoxic-ischemic brain injury. J Clin Invest 101:1992-1999

47. Chen J, Nagayama T, Jin K et al (1998) Induction of caspase3-like protease may mediate delayed neuronal death in the hippocampus after transient cerebral ischemia. J Neurosci 18: 4914-4928

48. Tamatani M, Mitsuda N, Matsuzaki H et al (2000) A pathway of neuronal apoptosis induced by hypoxia/reoxygenation: roles of nuclear factor-UB and Bcl-2. J Neurochem 75:683-693

49. Wang CX, Shuaib A (2002) Involvement of inflammatory cytokines in central nervous system injury. Prog Neurobiol 67: $161-172$

50. Kuribayashi K, Mayes PA, El-Deiry WS (2006) What are caspases 3 and 7 doing upstream of the mitochondria? Cancer Biol Ther 5:763-765

51. Lakhani SA, Masud A, Kuida K et al (2006) Caspases 3 and 7: key mediators of mitochondrial events of apoptosis. Science 311:847-851

52. Yin W, Cao G, Johnnides MJ et al (2006) TAT-mediated delivery of Bcl-XL protein is neuroprotective against neonatal hypoxicischemic brain injury via inhibition of caspases and AIF. Neurobiol Dis 21:358-371

53. Susin SA, Daugas E, Ravagnan L et al (2000) Two distinct pathways leading to nuclear apoptosis. J Exp Med 192:571580

54. Yoshida H, Kong YY, Yoshida R et al (1998) Apaf1 is required for mitochondrial pathways of apoptosis and brain development. Cell 94:739-750

55. Cheung EC, Melanson-Drapeau L, Cregan SP et al (2005) Apoptosis-inducing factor is a key factor in neuronal cell death propagated by BAX dependent and BAX-independent mechanisms. J Neurosci 25:1324-1334

56. Kroemer G, Martin SJ (2005) Caspase-independent cell death. Nat Med 11:725-730

57. Dumont C, Durrbach A, Bidere N et al (2000) Caspase-independent commitment phase to apoptosis in activated blood $\mathrm{T}$ lymphocytes: reversibility at low apoptotic insult. Blood 96: $1030-1038$

58. Yu SW, Wang H, Poitras MF et al (2002) Mediation of poly(ADP-ribose) polymerase-1-dependent cell death by apoptosis inducing factor. Science 297:259-263

59. Cao G, Pei W, Ge H et al (2002) In vivo delivery of a Bcl-xL fusion protein containing the TAT protein transduction domain protects against ischemic brain injury and neuronal apoptosis. J Neurosci 22:5423-5431

60. Zhang X, Chen J, Graham SH et al (2002) Intranuclear localization of apoptosis-inducing factor (AIF) and large scale DNA fragmentation after traumatic brain injury in rats and in neuronal cultures exposed to peroxynitrite. J Neurochem 82:181-191 
61. Zhu C, Wang X, Huang Z et al (2007) Apoptosis-inducing factor is a major contributor to neuronal loss induced by neonatal cerebral hypoxia-ischemia. Cell Death Differ 14:775-784

62. Zhu C, Qiu L, Wang X et al (2003) Involvement of apoptosis inducing factor in neuronal death after hypoxia-ischemia in the neonatal rat brain. J Neurochem 86:306-317

63. Ness JM, Harvey CA, Strasser A et al (2006) Selective involvement of BH3-only Bcl-2 family members Bim and Bad in neonatal hypoxia-ischemia. Brain Res 1099:150-159

64. Kuan CY, Whitmarsh AJ, Yang DD et al (2003) A critical role of neural-specific JNK3 for ischemic apoptosis. Proc Nat Acad Sci USA 100:15184-15189

65. Shibata M, Hattori H, Sasaki T et al (2002) Temporal profiles of the subcellular localization of $\mathrm{Bim}$, a $\mathrm{BH} 3$-only protein, during middle cerebral artery occlusion in mice. J Cereb Blood Flow Metab 22:810-820

66. Carloni S, Carnevali A, Cimino M et al (2007) Extended role of necrotic cell death after hypoxia-ischemia-induced neurodegeneration in the neonatal rat. Neurobiol Dis 27:354-361

67. Seta KA, Yuan Y, Spicer Z et al (2004) The role of calcium in hypoxia-induced signal transduction and gene expression. Cell Calcium 36:331-340

68. Zong WX, Thompson CB (2006) Necrotic death as a cell fate. Genes Dev 20:1-15

69. Liu J, Liu MC, Wang KK (2008) Calpain in the CNS: from synaptic function to neurotoxicity. Sci Signal 1:re1 